\title{
THE LIVED EXPERIENCES OF MARRIED HOSPITALITY MANAGEMENT STUDENTS IN A PHILIPPINE STATE UNIVERSITY: A PHENOMENOLOGICAL STUDY
}

\author{
Solomon D. Faller, Jr., D. M. \\ Leyte Normal University, Tacloban City, Leyte, Philippines \\ (kingfaller70@gmail.com) \\ DOI: https://doi.org/10.22452/jati.vol24no1.8
}

\begin{abstract}
A college degree has always been linked with success. This is the usual answer by people from underdeveloped countries like the Philippines. For Filipinos, finishing college is the most effective antidote to poverty, and parents consider it a precious dowry for their children. This phenomenological case study, using semi-structured interviews, reveals the transformative effect of a college degree upon the life prospects of young, married, millennial students. Their narratives illustrate the complex balancing between school life as students and family life as fathers and mothers. They tell an interesting story of pushing efforts of adapting family life to the needs of schooling. This specific case study shows how inclusive education can be supported by government authorities achieve socioeconomic development goals.
\end{abstract}

Keywords: college degree, college life, married millennial students, phenomenological study

\section{Introduction}

The life of married students while trying to earn a degree in college has been studied in various locations around the world. The factors that were considered in these studies are varied like academic performance, financial struggles, roles as parents, and challenges faced as married students to name a few. Statistics reveal that there is a significant percentage of married students globally. According to the analysis of the results of the National Postsecondary Study by the Institute for Women's Policy Research (2013), almost 25\% or four million college students in the United States (US) have children and are juggling multiple roles of parenting and schooling. Based on the same study, the African- 
American race has the highest percentage of college students with dependent children (37\%), American-Indian (33.4\%), Hispanic or Latino (25.3\%), white $(20.3 \%)$, and the lowest are the Asian or Pacific (17.6\%) (National Centre of Education, U.S. Department of Education, 2013). Getting married while in college is linked to various reasons, such as fear of isolation and feelings of insecurity, culture and emotions, avoiding pressure from parents' expectations, waiving of tuition fees, independence, feeling of security, and to coexist with someone that brings more fun and joy (Dillon, 2018). According to the Philippine Statistics Authority, 2010 Census of Population and Housing data, college undergraduates aged $17-24$ account for $22.3 \%$ of the total population. This is the stage where students are enrolled in college and includes married students. Within the same age bracket, only $9.9 \%$ are college graduates. These experiences can be true due to more challenging and more complicated roles of married college students at home and in school. Also, the traditional views about marriage have imposed more complex social responsibilities on married women students compared to the defined roles of single women students (Hoobler, Wayne, \& Lemmon, 2009). The study of Orion, Forosuelo, and Cavalida (2014) revealed that one factor associated with students dropping out from college is that of marriage and pregnancy, and linked teenage marriage to the high drop out from high school or college.

This study was inspired by the presence of married couples and students in a state university who were currently enrolled in a hospitality management programme at the time when the study was conducted. It endeavours to look into the lived experiences of these students who are balancing the multiplicity of their roles as college students and at the same time as parents. This phenomenon is true in all universities and colleges, local and abroad. Therefore, the findings of this study would serve as input in crafting more appropriate policies, programmes, and initiatives that should be undertaken in both private and government schools to cater to the special needs and attention of married college students who are currently mainstreamed into the majority.

\section{Review of Literature}

\section{Views about Married College Students}

Getting married while in college has been viewed differently by many in terms of its positive and negative implications and adjustments to the life of the student. Although some relationships will work and be successful, it is not true of all, and one thing that marriage will most likely bring while in college is the unwanted challenges that should be well thought out and given utmost consideration. 
Mullings (n.d.) revealed that although marriage can be one of the most personally fulfilling experiences in one's life, students who choose to marry during college years will face additional obstacles, increasing vulnerability to stress, mental health issues, and decreased academic performance. The study also emphasised the essence of time management skills of the student as a factor associated with good academic performance as a means to cope with the more complex and hectic schedule of married college students.

Studies on marriage during university cover much more than fidelity and time issues, and found that the fear that they will not find another is a leading cause of student marriage; many marriages at the ages of 19-23 have resulted from such insecurities (Dillon, 2018).

\section{Challenges and Struggles of Married College Students}

College students with children are confronted with various challenges in obtaining a college degree. According to the results of the Institute for Women's Policy Research (2013), student parents have higher unmet financial needs, and, eventually, leave education with accumulated debt. Students who decided to get married during college may experience unique challenges and responsibilities, which include financial and conflicting social experiences (Archer Education, 2019). Students, who at the same time are parents, always experience difficulty in budgeting their time every day with $40 \%$ working full time while more than half spend 30 hours per week on care-giving activities (Institute for Women's Policy Research, 2013).

Family issues or with the spouse are also a potential problem when not properly discussed and communicated like unclear expectations that may progress to a more serious problem of distrust, doubt, resentment, anger, and envy (Archer Education, 2019).

Married students find financial assistance and scholarships more difficult to access compared to single students who have more or less an appropriation from the government. In the US, married students' financial aid is governed by certain policies and regulations like they are required to account for the amount of assistance that they received from the government, and this is behind the fact that what they get is not enough compared to their needs.

\section{Coping Mechanism}

However, there are good points of being married while in college. The importance of higher education as a way towards development and having a high impact is well appreciated by many nations (Wong, Ahmad Nasharuddin, \& Kamisah Binti Ismail, 2015). In most countries worldwide, married college students are being offered many scholarships and financial assistance opportunities. For example, in the US, the Ed Bacome Scholarship of Ohio State 
University-Columbus caters for married students as their primary clients, the Indiana University has the David H. Runyon Scholarship to assist married mothers, and the Virginia Common wealth University, Richmond, has a fund for married graduate students (Archer Education, 2019). Married students' social life may significantly differ compared to those who are single. However, married students should not isolate themselves from the group and peers. They are advised to get involved in school, join student organisations, engage in sports and in other team-based activities and to stay connected with their peers in school. As cited by Rains and Young (2009), social support is an important factor that controls and protects a person from stress. Hence, in order to make their lives easier, married college students may consider ensuring the support of the other spouse who can give the best social support as the best coping mechanism. This was supported further by Meehan (2003), in that married students have better ways of coping and adjusting to the situation when there is adequate social support from friends and family members.

\section{Academic Performance of Married Students}

If getting married while in college can offer a supportive environment like having an understanding spouse, it may have positive effects and benefits on the academic performance of the student. Married students may perform better in school because they have better academic adjustment due to the support of their spouse and a positive husband-wife relationship, and their maturity level is more focused on accomplishing their schooling (Wasden, 2010). The study of Wasden (2010) on married versus non-married students revealed that married students have a higher Grade Point Average (GPA) compared to their non-married counterparts, and so he was able to conclude that it is not disadvantageous to get married while pursuing college education.

Moreover, the study on the Marital Status and Age Predictors of Academic Performance of Students of College of Education in North-Eastern Nigeria supports the findings that marital status does not significantly predict the academic performance of students in Colleges of Education, and that one's commitment, belief, confidence and self-efficacy may tend to predict one's academic performance (Amuda, Bulus, \& Joseph, 2016). The study further reveals that the possible reason for failure is due to the lack of adjustment, social problems, and satisfying experiences that seem to lead to dissatisfaction and failure, and result in an incapacitated academic performance (Amuda et al., 2016).

The study on the Impact of Domestic Responsibilities on the Academic Achievement of Married Women in College of Education has also confirmed that the academic performance of married students is not affected by marital status. 
Married women are heavily in charge of almost all the household works, such as cooking, maintaining the house, care of the children, providing the basic responsibility to the husband like sexual satisfaction, teaching and guiding the children, and many other tasks as mother and wife. However, they still have good performance as students in school (Sa'ad, 2014). In this study, the female married students were found to have better CGPA of 2.54 compared to those unmarried and male students in the College of Education, Azare (Sa'ad, 2014).

\section{Research Questions}

This study sought to document the lived experiences of married college students in a state university. The conduct of this study was guided by the following questions.

1. What are the actual experiences of married college students and how do they balance their two major roles as students and as parents?

2. What are the major issues and problems experienced by married college students, specifically in school and at home or family?

3. What are the major factors that motivate married college students to pursue and sustain their efforts to finish college?

4. What possible experienced-based recommendations can be deduced to address the concerns of married college students in order to increase the probability of finishing the degree sought?

\section{Theoretical Framework}

One common characteristic among the informants of this study is that they have low socio-economic status. Socio-economic status impacts many facets of life, leading to diminished access and success in higher education in the United States (Erk, 2013). Consistent with the proposition was the point of view of Payne (1996, 2005), Kerbo (1991), and Berk (2003), who said that individuals with low socio-economic status have fewer resources in health, mentoring, income, role modelling, and support systems that provide the necessary acumen to succeed in higher education. The Organisation for Economic Cooperation and Development (OECD), which conducted a large-scale assessment in many countries worldwide, and also the Programme for International Student Assessment (PISA) concluded that socioeconomic background largely deals with economic, social, and cultural status.

This study is anchored on the conceptual model authored by Pern and Thomas (2008) who examined socio-economic status and its impact on student success within the context of psychology, sociology, economics, and education. 
The model further assumes that family, school, social, economic, and political context influence student success (Erk, 2013). The model of Pern and Thomas (2008) elaborated on the four (4) contexts concerning how they impact student success.

Socioeconomic status is the social standing or class of an individual or group and it is often measured as a combination of education, income, and occupation, and examinations of socioeconomic status often reveal inequities in access to resources, plus issues related to privilege, power, and control (American Psychological Association, 2019). These include not just income but also educational attainment, financial security, and subjective perceptions of social status, social class, quality of life attributes, as well as the opportunities and privileges afforded to people within society, and is relevant to all realms of behavioural and social science, including research, practice, education, and advocacy (American Psychological Association, 2019)

Sociology is the science of society, social institutions, and social relationships; specifically the systematic study of the development, structure, interaction, and collective behaviour of organised groups of human beings; the scientific analysis of a social institution as a functioning whole and as it relates to the rest of society (Merriam-Webster Dictionary, 2019). Sociology encompasses social stratification, which is the allocation of individuals and groups according to various social hierarchies of differing power, status, or prestige. Although divisions are often based on gender, religion, or race and ethnicity, the present entry focuses largely on socioeconomic inequalities, and, for the most part, leaving other forms of social inequality to other entries (Andersen, 2014). Social stratification, as explained by sociologists, means social hierarchies with those at the top being more powerful and having greater access to power and resources while access to education, and barriers to education, such as systemic racism, are one factor that perpetuates inequality (Cole, 2019).

\section{Methodology}

\section{Research Design}

This is a descriptive phenomenological study on the lived and actual experiences of hospitality management students of a state university in the Philippines who are married and who also undertake another important role as parents. The student-informants of this study were currently pursuing the Bachelor of Science in Hotel and Restaurant Management (BSHRM) at the time this study was conducted. The design is deemed appropriate and fit for this kind of study because it allows one to explore and document the real life experiences of the informants about a given phenomenon. Phenomenology is a sober reflection on 
the lived experience of human existence that must be thoughtful, and, as much as possible, free from theoretical, prejudicial, and suppositional intoxications (van Manen, 2007).

According to the website of the Centre for Innovation in Research and Teaching (n.d.), Grand Canyon University, phenomenology is a methodology in research that exemplifies the actual experiences of a person or individuals and is based on the academic disciplines of philosophy and psychology. A phenomenological study attempts to set aside biases and preconceived assumptions about human experiences, feelings, and responses to a particular situation and it allows the researcher to delve into the perceptions, perspectives, understandings, and feelings of those people who have actually experienced or lived the phenomenon or situation of interest (Centre for Innovation in Research and Teaching). The study involved direct investigation of the cases of married college students and their very own ways of trying to survive college life, and, finally, to earn a degree. It was carried out through the conduct of informal, casual but in-depth conversations and interviews with the student-informants.

This study has employed particularly the Husserlian descriptive phenomenology and the phenomenological psychology of Colazzi (1978). The qualitative research approach was developed by Edmund Husserl, which is centred on "essence", and, as defined by Husserl, it is the "very central core of reality, it is the meaning, and if one has the grasp of the essence of something, he understands very much also its meaning" (Lauer, 1958). Part of Husserl's approach is the phenomenological reduction. This is a concept of setting aside momentarily all the factors that may contaminate the investigation, such as the researcher's own perceptions, assumptions, and knowledge about the assumption under study. The challenge here is to isolate the pure phenomenon from what is already known (Speziale \& Carpenter, 2007).

\section{Research Setting}

The venue of the study is a government university in the Province of Leyte, Philippines. Being a teacher-training university, its biggest department is the College of Education, which comprises $50 \%$ of the total population of the university. The university also offers the Bachelor of Science in Hotel and Restaurant Management (BSHRM) under the College of Management and Entrepreneurship. The enrolment in this programme is varied and students have different backgrounds in terms of age, marital status, socio-economic standing, including the reasons why they have chosen the programme in college.

The university is also the number one producer of hospitality management graduates in the region and the supplier of industry workers for 
hotels, restaurants, fast food chains, travel agencies, airline companies, and other related establishments in Tacloban City and Eastern Visayas. For School Year 2017 and 2018, the university produced a total of 503 graduates of the BSTHRM and BSHRM programmes.

\section{Sampling}

The student-informants for this study were purposively identified and selected from among the students of the College of Management and Entrepreneurship, particularly those who were currently enrolled in the Bachelor of Science in Hotel and Restaurant Management programme. One of the important factors that was considered by the researcher in selecting the informants for this study was the marital status in that they should be married; either a civil wedding or in church. The selection of the informants did not consider their year level in college, number of years of marriage, with or without child/children, number of children, or employment.

\section{Data Collection}

The researcher first ensured that the student-informants were willing to share their personal real experiences and their day-to-day life as college students in the university, as well as their daily lives as parents, wives or husbands. The informants, after agreeing to the interview with the researcher, were given the opportunity to choose the venue and time of the interviews that were most convenient and comfortable for them. One couple, who are both students in the university, finally decided to have the interview at the residence of the researcher after the schedule of classes for the reason of privacy, while the other four informants were interviewed at the office of the researcher. The data collection was made through semi-structured interviews and focus group discussion (FGD) using prepared guide questions in order to extract the lived experiences of married college students who are currently enrolled in the BSHRM programme of the university.

Before the interviews and discussions in the two venues, the studentinformants were briefed about the study and its purpose. The first in terview with the couple lasted for two hours while the second interview and focus group discussion with the other four informants lasted for more than an hour. The responses of the student-informants during the interviews and focus group discussions were personally recorded by the researcher. The recorded responses were personally transcribed by the researcher for higher accuracy and correctness of the data. 


\section{Data Analysis}

The data analysis for this phenomenological study adopted the Colazzi approach, which proposed an objective investigation of a phenomenon. It is a method that remains with human experience as it is experienced and can only be undertaken by means of a phenomenological method of description (Colazzi, 1973). The method involves reading and familiarising oneself thoroughly with the descriptions of the experiences and extracting and formulating significant statements from the descriptions. Then it proceeds with the interpreting and formulating of the meaning of the statements and crafting the cluster themes from the formulated meanings. The result is then integrated into the description of the phenomenon under study, which should be described profoundly and exhaustively. The last step is to validate the result to check its consistency with the actual experiences of the informants.

\section{Reflexivity}

The researcher is a professor in the department of the university where these married students are enrolled and are trying to survive in college. The phenomenological approach used in this study allows the researcher and other stakeholders who may directly or indirectly influence this struggle of married college students and to empathise and understand their way of life and their condition in the university.

\section{Results and Discussion}

Using the Colaizzi (1978) method of analysing qualitative data, four (4) themes were derived and formulated from the shared experiences of the studentinformants. The formulated themes are (1) the everyday experiences of married college students; (2) balancing dual roles as students and as parents; (3) challenges faced by married college students; and (4) the push to continue and survive in college.

\section{The everyday experiences of married college students}

The student-informants are no longer considered as the "normal type of students" when compared to the majority who are presumed to be single and still have the luxury of time to focus solely on their studies. The daily routine of single and married students is very different in many aspects, such as time allocation, prioritising things to do, and the manner of doing things, both in the school and in their houses. Married students have realised the importance of a single minute, that is why most of them were forced to implement their own time management plans. They are now very good at identifying things that should be prioritised over those of lesser importance. They do and accomplish tasks 
quicker and they try to find ways to save time and effort whenever applicable. Here are some of the significant responses of the informants with regard to their day-to-day life in school and at home.

"May mga meetings ha school nga diri na kami nakaka attend, kasi gin prioritise namon an amon anak ngan pamilya", so kon pwede diri nala mag api, diri nala kami kay better nga atenderan nala namon amon pamilya" (There were meetings in school that we cannot attend because we need to prioritise our children and family, so, if it is allowed, we will not attend because it's better to attend to our families).

"Usa gihapon siguro mas mature na kami mag huna-huna hin mga butang, not like before nga sarili la it amon gin huhuna-huna" (One thing is that we are more mature in thinking about some things, not like before when we were only thinking about ourselves).

"Nasulod kami ha school ngan na attend ha klase nga upod it asawa ngan dara namon ha klase it am baby, kay waray nagmaman gno" (We go to school and attend classes together with my wife and we used to also bring our baby to class because there is no one to attend to her).

"Dako na kaibahan hit amon life yana compare hit waray pamilya, kay hadto pagmata imo la it aasikasuhon, so bisan late na magmata okay la kay ikaw man la, yana kinahanglan very early mamata kay damo it aasikasuhon before makalakat ha eskwelahan. Aadamon it kinahanglanon hit bata, pagkaon, bado tanan gagamiton pati gihapon it kailangan hit asawa, manlilimpyo ha balay, magluluto anay ngnan damo pa" (We have a different life now compared to those who are single because, before, we only attended to our personal needs, so we could wake up late. Now, we need to wake up early because we need to prepare many things before we can leave for school, like the needs of the baby, food, clothing and also the needs of my husband, clean the house, cook and many more).

It is true enough that being married adds complexities and difficulties into a complex student life in college. A married life in college is full of hardships compared to a single life considering the many responsibilities that are imposed on married individuals (Study Moose, 2015). The informants have narrated their very own complex difficulties as married college students, and below are some of what they have shared. 
“Marisyo nga makapoy it student nga may baby, enjoy kami kay may liawan nga baby pero doble sakripisyo para maatenderan it akon pamilya, ngan diri liwat mapabay-an hin duro it pageskwela, kay gusto man gihap makatapos" (The life of a student with a baby is happy but tiring, we enjoy it because we have a baby that makes us happy, but the sacrifice is double just to attend to my family and at the same time not to sacrifice also my studies because I want to finish it).

"Ha amon mga edad, ako 28 yrs old dapat natrabaho na kami maiha na unta pero kay nauna man an pag-asawa, pero diri liwat magbasol kay ada man it pamilya" (At our age, I am 28 years old, I am supposed to be working long time ago, but because we got married early; but we have no regret because we have our family).

"Single parent ako may duha nga anak, ngan nagtratrabaho ako as kabullig para maka eskwela, nagmamangno ako hin upat nga mga anak hit akon agaron" (I am a single parent with two children, I am working as a house helper in order to sustain my studies, I am taking care of the four children of my landlord).

A married life in college is socially limiting and most married men or women on campus are in a life of their own, they have a lot to think about and many places to be at the same time; they rarely have time to socialise or engage in events within the school (Study Moose, 2015).

\section{Balancing dual roles as students and as parents}

The life of a college student is complex but it becomes more challenging and complicated when the role of wife or husband and/or parent is added to it. It entails multi-tasking and excellent budgeting and management of their time in order to accommodate the responsibilities in the family and the equally demanding school related activities and requirements. Motherhood responsibilities impose a large burden on students' shoulders, while the academic community focuses mainly on success, development, and never-ending competitions without providing any support, therefore, taking on motherhood along with studies is not considered normal in universities (Moghadam, Khiaban, Esmaeilli, \& Salsali, 2017). The necessity to balance these dual responsibilities has been confirmed by these married student-informants through their responses during the interviews.

"Natutunga it oras hit mga requirements nga dapat ipasa ngan baby, pero Diri kami naawod, nga may anak" (Our time is divided to comply 
with the requirements that we need to submit and our baby, but we are not ashamed that we have a baby).

"Iginpaparayaw ko nga may asawa ako, nga kasal kami, open kami about amon life ha amon mga clasmates" (I am proud of my wife and we are married, we are open about our life to our classmates).

"It amon pamaagi para magampanan namon it amon roles as parents and students, ako early Nagios, para diri malate ha school, pagpakaon hit bata, para makalakat dayon ha school" (Our way of coping with our roles as parents and as students, I usually wake up early in the morning so that we will not be late to school; feed the baby so that we can go to the school early).

"It akon husband na work liwat para kami mabuhi, so ako gud as wife it naniniguro parte ha balay mga trabahoon, especially nga it akn asawa diri mahilig bumulig hit mga trabahoon ha balay" (My husband is working so that we will survive, so it's really me who does all the household chores, especially as my husband is not fond of helping with things that must done at home).

"Para matagan hin tama nga attention it akon pamilya at the same time it akon pageskwela, kinahanglan gud an tama nga pagbudget hit imo oras, time management, ngan dapat waray time nga masasayang" (So that we can attend to our family and also our studies, we really need to strictly budget our time, time management, and to make sure that no time is wasted).

A woman may enthusiastically embrace the simultaneous roles of mother and student; however, undertaking these two roles, even in ideal conditions, can pull one person in two directions (Springer, Parker, \& Leviten-Reid, 2009). Combining motherhood and studying without compromising the activities of either one is a great dilemma for student mothers (Moghadam et al., 2017). The female student-informants of this study have shared their experiences of being a mother, and, at the same time, as a student.

"Multi-tasking talaga ako ha balay, ngan kon may vacant nga time ha school, mauli gud ako ha balay to attend to my son ngan para makatrabaho hin mga trabahoon ha balay" (I do multitasking at home, if I have vacant time at school, I will go home to attend to my son and to work at home). 
"My role as a wife, I also attend to the needs of my husband, like pag asikaso hit akon husband upod na gihapon it paglambing hit husband responsibilidad ko ito as wife para maupay it pamilya" (My role as a wife is to attend to the needs of my husband to bond with him as that's part of my responsibility so that there will be good relationship in the family).

"It amon weekened diri pareho hit iba nga time to relax, kay kami mas damo it kinahanglan atenderan pag weekend tanan nga trabahoon ha balay, maglalaba, manlimpyo, mga anak, so kon may school activities ha weekend, dako gud ito nga problema ha akon" (Our weekend is not like the other students, a time to relax, because we have many things to attend to. We need to work at home, wash clothes, clean the house, and also attend to the children. If there are school activities that are set during the weekend, it's really a big problem for me).

\section{Challenges faced by married college students}

Squeezing personal time into your already hectic schedule may seem like a nearly impossible task whilst balancing marriage and college (Mullings, n.d.). This is one of the many challenges confronting married college students. It may not be surprising because college life in a university in itself is complex and hard because of the numerous tasks and requirements that a student has to comply with. Getting married while in college is expected to add complexities and challenges when the roles and responsibilities of a wife or husband are added to it. The married college student is expected to be good at achieving a balance between personal life and school life. The student-informants have narrated their respective true-to-life experiences, and below are some of their responses.

"Waray mabibilinan, kay waray iba nga mabibilinan nga relatives han amon baby, gin allow kami, waray palisiya nga bawal magdara hin baby ha classroom mentras na attend hin klase" (None of our relatives want to take care of our baby, and I presume that it is allowed and there is no policy that prohibits bringing our baby to class).

"Waray kami nafefeel nga insecurities, it akon mindset nauna la kami maabot man nga kamo hini nga sitwasyon" (We have no insecurities, to my mind I said we just got married ahead of them, and there will be a time that they will also be in the same situation).

Colleges and universities are not exempt when it comes to the issue of bullying, and with the noticeable situation of married college students, which is different from the majority single students, this makes them susceptible to such a 
problem. Although some married students who are more exposed and experienced can easily cope with it, many are still trapped in this situation. Bullying can occur anywhere, and its occurrence can have short- and long-term effects on its victims; it is best understood as a student health issue - and a larger public health issue - that endangers the well-being of individuals (Rich, 2019). The informants have also talked about their exposure to bullying while they are in school, and they have shared their experiences concerning this phenomenon.

"Waray kami experience nga bullying with classmates, welcome kami han amon classmates, tanggap nira an situation, accepted nalilipay hira nga may baby kami, waray complaint by classmates, damo it nakugos hit bata" (We have not experienced bullying so far by our classmates, they accepted us and our situation, they are happy that we have a baby, no complaint so far from our classmates and many of them would share in cuddling our baby).

"One time one teacher asked about dara dara la niyo it nga bata, an tono han pagpakiana diri maupay, pero damo nga teachers nalilipay ngan positive an ira reaction ngan mas concerned an mga teachers, like nauran kon may paying" (One time a teacher asked us why are we bringing our baby to school and the tone of her voice was not good. Most of our teachers are happy and have positive reactions and they are more concerned about the safety of our baby).

“May mga students nga nagbu-bully ha akon, kay kon diri ako nakaka attend hit mga activities ha school, mayakan it akon mga classmates nga kay amo kay nag-inasawa ka man hin early. May mga tawo ha school nga diri na intindi hit amon sitwasyon" (There were students who have bullied me, because there are times that I cannot attend the school activities and then some of my classmates would say, it's because you married early. There are people in school who cannot understand our situation).

"May mga teachers nga diri nakarawat hit amon reason ngan explanation labi kon may mga time nga late kami, diri kami nakaka submit on time hit mga requirements ngan projects" (There are teachers who do not accept our reasons and explanation when we are late coming to class or if we cannot submit the requirements and projects on time). 
"May mga students nga nagyayakan hin diri maupay nga jokes about hit amon sitwasyon" (There are students who usually say bad jokes about our situation).

Financial hurdles are another common problem for young couples, especially for those married students who are then forced to manage their finances carefully. According to Kerkman, Lee, Lown, and Allgood (2000), financial management behaviour and the perception of how well finances were managed are significantly related to marriage satisfaction. This topic was one of the prominent discussions during the interviews and the informants have divulged the realities about it.

“Dako liwat nga problem it financial, pagbudget para family, mga anak, ngan mga aramutan ngan projects ha school, may mga cases nga I like to go to school and attend classes, kaya lang no money even for fare, kasi kon may gamay na money para basic needs nala anay ha balay and the children" (Financial is also a big problem for us, for our children and family, we need to contribute for our projects in school, there were cases that we really would like to go to school and attend our classes but we don't have money even for fare, because sometimes if we have limited budget, we just prioritise our needs at home and the children).

"An amon la usa nga medyo makuri kay diri gud conducive an lugar para hin bata kay mapaso, maaringasa, ngan waray lugar nga pwede kadtuan para hit sugad ha amon it sitwasyon" (One of our difficulties is that the place is not really conducive for the baby, it's hot, noisy and there is no available place or area for those with cases like us).

"May mga time nga nag-aaway kami nga mag-asawa, nauupod it kabataan ha problema, sugad ngani hito apektado gud it tanan labi na it pag-eskwela, siyempre diri ka makaka focus ha eswelahan" (There are times that we quarrel as husband and wife and our children were also affected by the problem. In times like this everything is affected, especially my studies, and I cannot really focus in school).

\section{The push to continue and survive in college}

Married students need twice as much motivation to that of their single contemporaries in order to survive and to finish their college education. There could be various reasons, such as individual advancement, professional, and career placement, and growth. The study of Knutsen (2011) revealed that the main factors that motivate students to pursue higher education can be extrinsic, 
such as to increase job opportunities and intrinsic, which is to advance personal growth. The high motivation among the student-informants to pursue their studies despite their current situation was very evident in their responses.

“Diri man gud makuri hin duro in sugad hini nga life, siguro financially yes kay naasa pa kami ha parents, salit naniniguro kami makatapos, magradwar gud kami" (It's not really that difficult like our life now, maybe because we are still financially dependent on our parents, that is why we are really doing our best so that we can finish and we will graduate).

"Para ha akon, han students easy life, yana nga may family na ako happy na ako, kay komo tikang ha broken family, nagin leksyon ko an akon experience komo from broken family, so kon akon na pamilya tatalinguhaon ko nga okay an akon pamilya. Nadiri ako nga maranasan hit akon kalugaringon nga pamilya" (Students' life is easy, but now that I have a family and coming from a broken family, it's a lesson for me, so for my family I will really do my best that my children will not experience the same).

"Masakit gad ha buot nga nag-aalaga ako hin iba nga mga anak, it akon kalugaringon nga anak di ko namamangnuan, so maniguro ako makatalwas para makauli ako ngadto hit akon mga anak ngan ako na it magmamangno ha ira" (It's really painful to think that I am taking care of other people's children, but my own children I am not with them to take care of them, so I will really do my best so that I can finish my schooling and go home to my children).

"Naniniguro bisan makapoy, always exhausted physically, diri la para ha akon, una gud para ha pamilya ngan mga anak, so that diri hira mag suffer in the future pareho hini nga akon experience yana" (I am doing my best even if it is exhausting physically, not only for myself but for my family and children).

\section{Conclusion}

Married college students are not the usual typical single college students. They have a more complex responsibility that requires good time management and budgeting in order to accommodate and attend to their two major roles - as student and as wife or husband and as parents. The life of married students requires full balancing of their dual roles and responsibilities in school and at home with their family. Multitasking is a reality that should be embraced by 
married college students. They are confronted with big challenges like multiple roles, stiff family demands and school requirements, financial problems, and the incidents of maltreatment by other students and even teachers. This is consistent with the perspectives of Payne (1996, 2005), Kerbo (1991), and Berk (2003) who contend that socio-economic status is a determinant of one's higher education success. They move every day in an environment that is not very appropriate for their condition like the absence of school facilities that would fit their special needs as married parent-students, scheduling of school activities that do not consider their status as "not the usual college students", inconsiderate teachers for their justifiable excuses, and also irresponsible remarks from other students. These realities that have been experienced by married students is explained by the science of society, which explains about social institutions, social relationships, social hierarchies and the status of the individual in a society. But despite these realisms, they have high motivation to pursue and survive in college and earn a degree, which is largely influenced by extrinsic and intrinsic motivators - the personal and family.

\section{Recommendations}

In order to effectively address this issue, a clear policy should be implemented by the university concerning how to handle special cases of students like those who are married and for those with children and families. It should clearly stipulate guidelines on what is allowed and what is not (e.g., bringing babies/children to school, priority lanes when enrolling and paying).

In relation to instruction and academics, the school should carefully consider the scheduling of activities, the timing and the length of time, and the schedule of classes that should be given to married students. It is likewise suggested that teachers should have clear and concrete strategies concerning how to treat them inside the classroom, particularly in respect of the submission of requirements and other academic concerns in order to help make the life of married students easier given their complicated and complex roles.

The school should develop programmes that cater for and address the needs and concerns of married students. It should initiate and implement measures to protect the interests and rights of married students in the university against bullying, bad jokes and irresponsible remarks by other students and teachers that may affect the morale of married students.

It is also recommended that facilities should be made available and accessible in the university like rest and breastfeeding areas to make the life of married students easier, comfortable, and safe. It is likewise beneficial and helpful to activate the role of relevant offices in the university like the Office of 
Student Affairs and the Guidance Office in initiating activities that would boost the morale of married students, thereby increasing their chance of finishing their schooling in college.

\section{References}

American Psychological Association. (2019). Socioeconomic status. Retrieved from https://www.apa.org/topics/socioeconomic-status

Amuda, B. G., Bulus, A. K., \& Joseph, H. P. (2016). Marital status and age as predictors of academic performance of students of colleges of education in the North-Eastern Nigeria. American Journal of Educational Research, 4(12), 896-902.

Andersen, R. (2014). Social stratification. Oxford Bibliographies. Retrieved from http://www.oxfordbibliographies.com/view/document/obo9780199756384/obo-9780199756384-0053.xml\#navigation

Archer Education. (2019). Married college students. Retrieved from https://www.campusexplorer.com/college-advicetips/CF0064F6/Married-College-Students/.

Berk, L. E. (2003). Development through the lifespan. Boston: Allyn and Bacon.

Center for Innovation in Research and Teaching. (n.d.). Phenomenology research overview. Website of Center for Innovation in Research and Teaching, Grand Canyon University. Retrieved from https:/cirt.gcu.edu/research/developmentresources/research_ready/phen omenology/phen_overview

Colaizzi, P. F. (1978). Psychological research as the phenomenologist views it. In R. Vale \& M. King (Eds.), Existential-phenomenological alternatives for psychology (pp. 48-71). New York: Oxford University Press.

Cole, N. L. (2019). What is social stratification, and why does it matter? how sociologists define and study this phenomenon. Thought Co. Retrieved from https:/www.thoughtco.com/what-is-social-stratification-3026643

Dillon, J. (2018). 4 pros and cons of getting married while studying at university. Retrieved from https://www.marriage.com/blog/relationship/gettingmarried-while-studying/

Erk, T. (2013). The college student as mother: A phenomenological examination of community college student experiences. Doctoral dissertation, Teachers College, Ball State University, United States. Retrieved from https://cardinalscholar.bsu.edu/bitstream/handle/123456789/197391/ErkT _2013-3_BODY.pdf?sequence=1 
Hoobler, J. M., Wayne, S. J., \& Lemmon, G. (2009). Bosses' perceptions of familywork conflict and women's promotability: Glass ceiling effects. Academy of Management Journal, 52(5), 939-957.

Institute for Women's Policy Research. (2013). College students with children are common and face many challenges in completing higher education. National Center for Education Society, US Department of Education. Retrieved from https://files.eric.ed.gov/fulltext/ED556715.pdf.

Kerbo, H. R. (1991). Social stratification and inequality: Class conflict in historical and comparative perspective (2nd Ed.). New York: McGraw Hill, Inc.

Kerkman, B. C., Lee, T. T., Lown, J. M. \& Allgood, S. M. (2000). Financial management, financial problems and marital satisfaction among recently married university students. Retrieved from https://www.academia.edu/24790560/Financial_management_financial_p roblems_and_marital_satisfaction_among_recently_married_university_s tudents

Knutsen, D. W. (2011). Motivation to pursue higher education. Doctoral dissertation, School of Graduate and Continuing Studies, Olivet Nazarene University. Retrieved from https:/digitalcommons.olivet.edu/cgi/viewcontent.cgi?referer=https://w ww.google.com/\&httpsredir=1\&article $=1024 \&$ con text=edd_diss

Meehan, D. C. N. (2003). Undergraduate students' adaptation to college: Does being married make a difference? Journal of College Student Development, 44(5), 670-690.

Merriam-Webster Dictionary. (2019). Definition of sociology. Retrieved from https://www.merriam-webster.com/dictionary/sociology

Moghadam, Z. B., Khiaban, M.O., Esmaeili, M. \& Salsali, M. (2017). Motherhood challenges and well-being along with the studentship role among Iranian women: A qualitative study. International Journal of Qualitative Studies in Health and Well-being, 12(1), 1-12.

Mullings, A. (n.d.). Marriage and academia: Finding the balance between marriage, school, and life. Association for Psychological Science. Retrieved from https://www.psychologicalscience.org/members/apssc/undergraduate_u pdate/marriage-and-academia-finding-the-balance-between-marriageschool-and-life

Orion, H. C., Forosuelo, E. J. D., \& Cavalida, J. M. (2014). Factors affecting students' decision to drop out of school. Slongan, 2(1), 1- 16.

Payne, R. K. (1996). Understanding and working with students and adults from poverty. Instructional Leader, 9(2), 1-5. 
Payne, R. K. (2005). A framework for understanding poverty (4th ed.). Highlands, TX: aha! Process, Inc.

Pern, L. W. \& Thomas, S. L. (2008). A conceptual model for understanding disciplinary approaches to student success. ASHE Higher Education Report (Special Issue: Theoretical Perspectives on Student Success: Understanding the Contributions of the Disciplines), 34(1), 11-34.

Rains, S. A., \& Young, V. (2009). A meta-analysis of research on formal computer-mediated support groups: Examining group characteristics and health outcomes. Human Communication Research, 35, 309-336.

Rich, B. (2019). Bullying in college - awareness, outreach, and prevention. The Quad. Retrieved from https://thebestschools.org/magazine/bullying-incollege/

Sa'ad, T. U. (2014). The impact of domestic responsibilities on the academic achievement of married women in college of education, Azare. Journal of Educational and Social Research, 4(7), 101-107.

Speziale, H. J., \& Carpenter, D. R. (2007). Qualitative research in nursing: Advancing the humanistic imperative (2nd ed.). Philadelphia, PA: Lippincott Williams \& Wilkins.

Springer, K. W., Parker, B. K., \& Leviten-Reid, C. (2009). Making space for graduate student parents: Practice and politics. Journal of Family Issues, 30(40), 435-457.

Study Moose. (2015) College life of single students versus college life of married students. Retrieved from https://studymoose.com/college-life-of-singlestudents-versus-college-life-of-married-students-essay

van Manen, M. (2007). Phenomenology of practice. Phenomenology \& Practice, 1(1), 11-30. Retrieved from http://www.maxvanmanen.com/files/2011/04/2007-Phenomenology-ofPractice.pdf

Wasden, B. (2010). Married vs. non-married students. Salt Lake City College. Retrieved from https://wasdenbrooke.weebly.com/uploads/5/7/2/2/5722340/researchfinal draft.pdf

Wong, S. K. E., Ahmad Nasharuddin, \& Kamisah Binti Ismail. (2015). Education loan repayment and performances: The Malaysian graduates perspectives. JATI-Journal of Southeast Asian Studies, 20, 158-172. doi:10.22452/jati.vol20no1.10 


\section{List of Student-Informants}

The student-informants for this study are as follows:

1. Marco

He is 29 years old and much older than the normal second year college student. He belongs to a broken family and was seldom in contact with his siblings and parents. He grew up with his relatives and he has decided to work for a living. It was only in 2016 that he decided to en rol in college where he met his wife who is a student in the same programme in the university. He is now a father of a month-old baby girl.

\section{Princess}

She is 19 years old and was only in first year college when she got married. She is now a mother of a month old baby. She is the only child in the family, and, despite her early marriage, her parents have decided to support her financially to continue her college education.

\section{Rose}

She is a second year college student taking a Bachelor of Science in Hotel and Restaurant Management in the university. She is 20 years old and got married in 2015. She is the mother of a 4-year-old son.

4. Nathalie

She is a mother to her 8-year-old son. She has been married for almost nine years, since 2009. At present, she is 27 years old, which according to her, if she did marry early, at her age, she should be working already.

\section{Anne}

Anne was 24 years old at the time this study was conducted. She has been married for seven years, since 2012, with two children - a six-year-old daughter and a five-year old son.

\section{Joy}

Joy has an extremely difficult life as a married student in college. She is a single parent of her two children, who at present, are left in her hometown under the care of her cousin. What makes her student life difficult is that she is not only a student and a single mother, but, at the same time, she is working as a house helper and taking care of four children for her employer. So, basically, she is balancing three major roles - college student, single parent, and house helper. 